\title{
Diversity of Xanthomonas spp. Associated with Bacterial Spot of Processing Tomatoes in Brazil
}

\author{
A.M. Quezado-Duval and C.A. Lopes \\ Empresa Brasileira de Pesquisa Agropecuária, Centro Nacional de Pesquisa de Hortaliças \\ Caixa Postal 218, 70359-970, Brasília, DF \\ Brazil \\ R.P. Leite Júnior \\ Instituto Agronômico do Paraná \\ Caixa Postal 481, 86001-970, Londrina, PR \\ Brazil \\ M.F. Lima \\ Empresa Brasileira de Pesquisa Agropecuária \\ Centro de Pesquisa Agropecuária dos Trópicos Semi-Áridos \\ Caixa Postal 23, 56300-970, Petrolina, PE \\ Brazil \\ L.E.A. Camargo \\ Universidade de São Paulo, Escola Superior de Agricultura “Luiz de Queiroz” \\ Caixa Postal 9, 13418-900, Piracicaba, SP \\ Brazil
}

Keywords: Lycopersicon esculentum, Xanthomonas axonopodis pv. vesicatoria, $X$. campestris pv. vesicatoria, $X$. euvesicatoria, $X$. gardneri, $X$. perforans, $X$. vesicatoria, pulsed-field electrophoresis, chemical control, races

\begin{abstract}
Bacterial spot has become a major problem in Brazilian processing tomato fields due to favorable environmental conditions, lack of resistant cultivars or lack of efficient chemical control. The occurrence of genetic groups/species of Xanthomonas associated with bacterial spot in tomato in Brazil was studied from 1995 to 2000, upon phenotypic and genotypic characterization of 447 strains collected in commercial fields in the Central-West and Northeast. The four recently described Xanthomonas species associated with bacterial spot of tomato were detected. The populations from the Central-West were mainly composed of $X$. gardneri (group D/race T2). Xanthomonas vesicatoria (group B/race T2) and $X$. euvesicatoria (group $\mathrm{A} /$ race T1) were also present in some fields but at low rates. In the Northeast, only $X$. euvesicatoria (group A/race T1) and $X$. perforans (group C/race T3) were found. Genetic variability was analysed using pulsed-field electrophoresis. Strains of $X$. euvesicatoria, which were collected mostly from an open pollinated variety, were more variable in contrast with those of $X$. vesicatoria, $X$. perforans, and $X$. gardneri. Further collection and characterization of 53 strains from 2002 and 2003 revealed that race $\mathrm{T} 3$ is already present in the Central-West associated with imported hybrid cultivars. Surveys on bacterial spot occurrence should be continuous in order to detect eventual changes in population composition.
\end{abstract}

\section{INTRODUCTION}

Previously distributed to southeast and northeastern states of Brazil, processing tomatoes are now concentrated in the Central-West, which accounts for approximately $80 \%$ of cultivated area. High technological cropping systems, which make use of hybrid cultivars and usually imported seeds, sprinkle irrigation, and mechanized sowing, transplanting and harvest are typical in the region, where yields range from 70 to $100 \mathrm{t} / \mathrm{ha}$ (tomato processing companies/Embrapa Hortaliças, 2001, unpublished). Among the 
tomato diseases, bacterial spot has become a major problem due to favorable environmental conditions ensured by sprinkle irrigation, lack of resistant cultivars or lack of efficient chemical control (Lopes et al., 2000).

Bacterial spot was until recently thought to be caused by a homogeneous group of strains of Xanthomonas campestris pv. vesicatoria. At present, however, it is accepted that this disease is caused by four different species comprising four genetic/phenotypic groups and three races: $X$. euvesicatoria (group A/race T1), $X$. vesicatoria (group B/race T2), $X$. perforans (group C/race T3) and X. gardneri (group D/race T2) (Jones et al., 2004). These species/groups/races can be reliably distinguished by genomic fingerprinting using different molecular techniques such as rep-PCR, restriction profiles of hrp genes, and rRNA sequence homology (Bouzar et al., 1999; Jones et al., 2000; Obradovic, 2004). Some phenotypic features are also related to the groups, such as the use of cis-aconitic acid and maltose, whole-cell protein profiles, reaction to monoclonal antibodies and hypersensitive reaction on tomato differential varieties. The latter is used for race determination (Jones et al., 1998a). Whereas groups A and B have a worldwide distribution, groups $\mathrm{C}$ and $\mathrm{D}$ are thought to be restricted to Mexico, Thailand and the USA and to Costa Rica and Yugoslavia, respectively (Jones et al., 2000). The occurrence of these species/groups/races in Brazil was not well known, but ten years ago, Brazilian strains of group A and B from producing regions of fresh market tomatoes were reported by Bouzar et al. (1994).

This study was carried out with a group of strains collected in processing tomato fields from 1995 to 2003. Preliminary results of this study have been published elsewhere (Quezado-Duval and Camargo, 2004; Quezado-Duval et al., 2003; Quezado-Duval et al., 2004). In this report, an overview of the population composition of xanthomonads associated with bacterial spot in Brazilian processing tomato and its dynamics during this period is presented.

\section{MATERIALS AND METHODS}

\section{Strain Collection}

Samplings were done in the contrasting edaphoclimatic regions represented by the Northeast (states of Pernambuco and Bahia) and the Central-West (states of Goiás and Minas Gerais) (Fig. 1). The first region was characterized by a warmer climate, fields of about 2 to 5 ha, of furrow or conventional sprinkler irrigation, and was mostly cultivated with the national open pollinated variety IPA-5. In the second region in high plateaux, the fields ranged from 20 to 50 ha, most of them irrigated by central pivot systems. Diseased leaves and fruits were collected randomly throughout the fields. Nutrient agar medium (NA) was used for isolation. Strains derived from single colonies were stored in phosphate buffer (pH 7.0) at room temperature. From 1995 to 2000, 447 strains obtained from both regions were characterized by pulsed-field electrophoresis (PFGE) and by amylolytic and pectolytic activity. Selected representive strains were further tested for the presence of $\alpha$ or $\beta$ proteins; utilization of maltose; in vitro sensitivity to copper, streptomycin and oxitetracycline; race determination in relation to tomato and pepper hosts; and presence of avirulence genes $a v r R x v$ and $a v r X v 3$ by PCR with specific primers (Bouzar et al., 1993; Astua-Monge et al., 2000). Additionally, 53 strains from the CentralWest collected in 2002 and 2003 were partially analysed (races, amylolitic and pectolytic activities, and maltose utilization) and incorporated in the overall analysis. Strains 75-3, XV56, and XG101 were included as reference of $X$. euvesicatoria, $X$. vesicatoria, and $X$. gardneri, respectively (Jones et al., 2000; Jones et al., 2004).

\section{PFGE of Digested Genomic DNA}

PFGE analysis was performed as described by Egel et al. (1991) with minor modifications. Genomic DNA from lysed agar-embedded cells of bacterial strains was digested with $\mathrm{Xba}$ I and the DNA fragments resolved in 1.2\% agarose gels prepared with 0.5X TBE running buffer. Electrophoresis was carried out in a CHEF-DR II apparatus 
(Bio-Rad Laboratories, Hercules, CA) at $12^{\circ} \mathrm{C}$ and $6 \mathrm{~V} / \mathrm{cm}$ of gel with pulse times of $4 \mathrm{~s}$ for $1 \mathrm{~h}$ followed by $15 \mathrm{~s}$ for $24 \mathrm{~h}$. The gels were stained with ethidium bromide $(0.5$ $\mu \mathrm{g} / \mathrm{ml})$. Co-migrating DNA fragments larger than $100 \mathrm{~kb}$ were compared and distinct banding patterns were considered as different haplotypes. Dice coefficients of similarity were calculated from the restriction fragment data for all pairwise strain combinations including strains 75-3, XV56, and with NTSYS-pc (version 1.70; Exeter Software, Setaukaat, NY). The cluster analysis was performed using the program SAHN of the same computational package and the UPGMA method. Bootstrap analysis was performed with 1,000 permutations through BOOD (version 1.0; A.S.G. Coelho, Laboratório de Genética Vegetal - DBG/ICB/UFG, Goiânia, GO, Brazil).

\section{Starch Hydrolysis, Pectate and Carbon Source Utilization}

For amylolytic and pectolytic activities, $10 \mu \mathrm{l}$ of bacterial suspensions $\left(\mathrm{A}_{600}=0.1\right)$ prepared in distilled water were placed, respectively, on NA medium amended with $1 \%$ starch, and on crystal violet-pectate (CVP) medium without crystal violet (Cuppels and Kelman, 1974). Bacterial growth surrounded by a translucid zone was considered positive for amylolytic activity. Pectolytic strains produced a depression in the CVP medium surface. For maltose utilization, bacterial suspension droplets were deposited on plates of medium C of Dye amended with $0.5 \%$ of one of the carbon sources described by O'Garro (1998). Bacterial growth was compared to plates with medium devoid of carbon after incubation for up to 5 days at $28^{\circ} \mathrm{C}$. Two plates were used per strain. The carbon test was performed with 55 strains representing the PFGE haplotypes. Maltose test was further carried out with the 53 strains collected in 2002 and 2003.

\section{Electrophoresis of Soluble Proteins}

Thirty-one strains were characterized by their protein profiles by silver stained one-dimensional electrophoretic separation (Bouzar et al., 1994). Electrophoresis was performed at $4^{\circ} \mathrm{C}$ by using a Protean II double slab vertical electrophoresis apparatus (Bio-Rad Laboratories).

\section{In Vitro Sensitivity to Copper, Streptomycin and Oxytetracyclin}

Bacterial suspension droplets of $5 \mu \mathrm{l}$ were deposited on NA medium amended with copper sulfate (50 and $200 \mu \mathrm{g} / \mathrm{ml})$, streptomycin sulfate $(25 \mu \mathrm{g} / \mathrm{ml}$ and $200 \mu \mathrm{g} / \mathrm{ml})$ or oxitetracycline hydrocloridrate $(25 \mu \mathrm{g} / \mathrm{ml})$. Streptomycin and tetracycline are the active ingredients found in antibiotics registered for use in tomato in Brazil. The confluent growth in three replicates was considered as a positive result (Bouzar et al., 1999). A total of 362 strains were analysed for all concentrations, except for the test with $200 \mu \mathrm{g} / \mathrm{ml}$ of streptomycin which was used to test only those resistant to the concentration of $25 \mu \mathrm{g} / \mathrm{ml}$.

\section{Pathogenicity Tests and Presence of Avirulence Genes}

Two plants of each of the susceptible cultivars Walter (tomato) and Early Calwonder (pepper) were inoculated with 72 strains, which included the PFGE haplotypes and representative strains from each tomato field. Bacterial cultures were obtained from colonies transferred from NA to nutrient broth and shaken (12,000 rpm) overnight at $28^{\circ} \mathrm{C}$. Plants with four to five true leaves (six and five weeks after sowing, respectively, for pepper and tomato plants) were spray inoculated with bacterial suspension of $5 \times 10^{7} \mathrm{CFU} / \mathrm{ml}$ ( $1: 10$ dilution of $\left.\mathrm{A}_{600}=0.3\right)$, and then maintained in a moist chamber for two days before being transferred to a greenhouse $\left(25\right.$ to $\left.35^{\circ} \mathrm{C}\right)$. Symptom development was daily monitored up to 21 days after inoculation. The strains pathogenic to pepper were then tested in a differential tomato and pepper genotype set (tomato: Walter, Hawaii 7998 and NIL216; and pepper: ECW, ECW10R, ECW20R, ECW30R and $\mathrm{PI} 235047)$. Bacterial suspensions of $5 \times 10^{8} \mathrm{CFU} / \mathrm{ml}\left(\mathrm{A}_{600}=0.3\right)$ were infiltrated in the adaxial leaf surface with an hypodermic syringe without the needle. The plants were maintained at $28^{\circ} \mathrm{C}$ in growth chamber under $12 \mathrm{~h}$ of fluorescent light, and observed for hypersensitive reaction development. The presence of avirulence genes avrRxv and 
avrXvT3 were confirmed for races $\mathrm{T} 1$ and $\mathrm{T} 3$, respectively. The genomic total DNA was isolated by CTAB method (Wilson, 1999) and PCR was carried out using primers RST27 and RST28 for $a v r R x v$, and RST88 and RST89 for $a v r X v T 3$ (Bouzar et al., 1994; AstuaMonge et al., 2000). The 53 strains from 2002 and 2003 were classified only according to races on tomato differentials.

\section{RESULTS AND DISCUSSION}

The genomic DNA digestion generated 11 to 16 fragments per strain, and a total of 50 fragments were analysed. Twenty-six haplotypes were distinguished among the 447 strains showing distinct patterns from the reference strains (Fig. 2). Cluster analysis of all data generated a dendrogram of similarity with four groups. The first group was the most polymorphic and comprised 17 haplotypes. This group included the reference strain of $X$. euvesicatoria (group A). The second group was represented only by three haplotypes without any reference strain. It was more closely related to the first group than the to the others. The third group had four haplotypes related to the reference strain of $X$. vesicatoria (group B). The last group was also formed by only three haplotypes, which included the reference strain of $X$. gardneri (group D). All strains were distinct lineages of the reference strains. It is still difficult to know if the intraspecific genetic variation found among the Brazilian strains in the groups reflects the overall variation of the species. However, if this hypothesis is not correct, and the species presents the same level of genetic variation, it is reasonable to associate the low polymorphism found, especially in the PFGE groups 2 (X. perforans), 3 (X. vesicatoria), and 4 (X. gardneri) with recent introduction events. These events could be associated with the use of imported seeds. Moreover, in general, the populations of these species were clonal within a field.

The PFGE groups were somewhat distinct in their phenotypic characteristics (Table 1). Out of the 447 strains, all of PFGE group 1 were classified as race T1P2 and T1P8; strains of PFGE group 2 as race T3; strains of PFGE group 3 as race T2, and strains of PFGE group 4 as race T2. This last group was the only one to utilize maltose as a sole carbon source (Table 1). All the phenotypic characteristics observed for each group were consistent with those reported in the literature for genotypic and phenotypic groups A, B, C and D (Jones et al., 1998a; Jones et al., 2000). Based on these results, strains of PFGE 1,2 , 3, and 4 were classified as $X$. euvesicatoria, $X$. perforans, $X$. vesicatoria, and $X$. gardneri (Jones et al., 2004).

The presence of avirulence genes $a v r R x v$ and $a v r X v 3$ were confirmed in all T1 and T3 strains, respectively. The majority of strains of PFGE group 3 was resistant to copper, whereas those of PFGE group 4 were resistant to streptomycin (Table 1). On the other hand, no strain from PFGE group 2 was resistant to streptomycin (Table 1). No strain was resistant to oxytetracycline, but this observation does not relate to control efficacy by the use of antibiotics.

Among the 53 strains from 2002 and 2003, 22 were race T2, amylolytic, pectolytic and maltose negative, and 31 were race T3, amylolytic, pectolytic and maltose positive. Therefore, these strains were most likely classified as $X$. gardneri and $X$. perforans, respectively.

In terms of distribution and frequency of species/groups/races, up to 1998, different species/groups occurred or predominated in the two producing regions (Fig. 2, Table 2). In the Northeast in 1996, $100 \%$ of strains belonged to X. euvesicatoria (group A, race T1). At that time, only a Brazilian open-pollinated cultivar was planted which had been developed in this region, with seeds produced locally. This fact possibly explains the greater polymorphism found within this group, relating to a longer period for population establishment. In 1998, besides group A, about two thirds of the strains were also classified as group $\mathrm{C}$, race $\mathrm{T} 3$, currently named $X$. perforans. At this time, some strains were isolated from an imported hybrid, all associated with this bacterial species (Table 2).

In the Central-West, initially, most of strains were of $X$. vesicatoria (group B/race T2), but some of $X$. euvesicatoria were also found. After 1997, $X$. gardneri (group D/race T2) was detected and became prevalent (Table 2). Since 2002, however, $X$. perforans was 
also detected (Table 2), whilst $X$. euvesicatoria and $X$. vesicatoria have not been found. Therefore, $X$. perforans and $X$. gardneri are apparently the most important species in the main producing areas in Brazil currently. Xanthomonas euvesicatoria and $X$. vesicatoria had a worldwide distribution, but $X$. perforans was thought to be restricted to Mexico, Thailand, and the USA, and X. gardneri to Yugoslavia and Costa Rica (Jones et al., 2000). Seed distribution might have contributed to the widespread dissemination of these species. Recently samplings of bacterial spot in tomato fields in Ontario, Canada, showed that $X$. gardneri and race T3 (X. perforans) were also becoming more prevalent in the last years (Warner, 2003). The preemptive nature of one species over another is still to be elucidated. However, the competitive nature of race T3 in the presence of T1 $(X$. euvesicatoria) was demonstrated and helped to explain the emergence and subsequent prevalence of T3 in Florida (Jones et al., 1998b).

\section{CONCLUSIONS}

Great diversity of Xanthomonas species associated with tomato bacterial spot was observed in Brazil, with different scenarios among the production regions analysed. Xanthomonas gardneri and $X$. perforans had not been reported in Brazilian tomato fields so far. However, there is no guarantee that they were not present before, since this is the first survey extensively done in the country. A detailed report on the outbreaks of $X$. gardneri in Central-West has been published (Quezado-Duval et al., 2004). The introduction of race T3 in this region, associated with imported seeds of hybrids, points out for the possible role of seeds as primary inoculum source and determinant of the population composition in a given period. In Brazil, there is no regulatory control concerning bacterial spot Xanthomonas spp. on tomato or pepper seeds. Surveys on bacterial spot occurrence in the field and in seed lots should continue in order to follow the dynamics of Xanthomonas population composition and help to address proper research efforts for disease control achievement.

\section{ACKNOWLEDGEMENTS}

Thanks to Embrapa, CNPq, and FAPESP for financial support, Jeffrey B. Jones, Isabel C. Bezerra, and Alice I. Nagata for technical advice, and Rafael Sant'Ana, and Luiz C. Rodrigues for assistance in field samplings.

\section{Literature Cited}

Astua-Monge, G., Minsavage, G.V., Stall, R.E., Davis, M.J., Bonas, U. and Jones, J.B. 2000. Resistance of tomato and pepper to T3 strains of Xanthomonas campestris pv. vesicatoria is specified by a plant-inducible avirulence gene. Mol. Plant-Microbe Interact. 13:911-921.

Bouzar, H., Jones, J.B., Minsavage, G.V., Stall, R.E. and Scott, J.W. 1993. Proteins unique to phenotypically distinct groups of Xanthomonas campestris pv. vesicatoria revealed by silver staining. Phytopathology 84:39-44.

Bouzar, H., Jones, J.B., Stall, R.E., Hodge, N.C., Minsavage, G.V., Benedict, A.A. and Alvarez, A.M. 1994. Physiological, chemical, serological, and pathogenic analysis of a worldwide collection of Xanthomonas campestris pv. vesicatoria. Phytopathology 84:663-671.

Bouzar, H., Jones, J.B., Stall, R.E., Louws, F.J., Schneider, M., Rademaker, J.L.W., Bruijn, F.J. and Jackson, L.E. 1999. Multiphasic analysis of xanthomonads causing bacterial spot disease on tomato and pepper in the Caribbean and Central America: evidence for common lineages within and between countries. Phytopathology 89:328335.

Cuppels, D. and Kelman, A. 1974. Evaluation of selective media for isolation of soft-rot bacteria from soil and plant tissue. Phytopathology 64:468-475.

Egel, D.S., Graham, J.H. and Stall, R.E. 1991. Genomic relatedness of Xanthomonas campestris strains causing disease on citrus. Appl. Environ. Microbiol. 57:2724-2730.

Jones, J.B., Stall, R.E. and Bouzar, H. 1998a. Diversity among xanthomonads pathogenic 
on pepper and tomato. Ann. Rev. Phytopathol. 36:41-58.

Jones, J.B., Bouzar, H., Somodi, G.C., Stall, R.E., Pernezny, K., Elmorsy, G. and Scott, J.W. 1998b. Evidence for the preemptive nature of tomato race 3 of Xanthomonas campestris pv. vesicatoria in Florida. Plant Dis. 79:395-398.

Jones, J.B., Bouzar, J., Stall, R.E., Almira, E.C., Roberts, P.D., Bowen, B.W., Sudberry, J., Strickler, P.M. and Chun, J. 2000. Systematic analysis of xanthomonads (Xanthomonas spp.) associated with pepper and tomato lesions. Intl. J. Syst. Bacteriol. 50:1211-1219.

Jones, J.B., Lacy, G.H., Bouzar, H., Stall, R.E. and Schaad, N.W. 2004. Reclassification of the xanthomonads associated with bacterial spot disease of tomato and pepper. Systematic Appl. Microbiol. 27:755-762.

Lopes, C., Santos, J.R.M., Ávila, C., Bezerra, I.C., Charchar, J.M. and Quezado-Duval, A.M. 2000. Doenças: identificação e controle. p.88-111. In: J.B.C. Silva and L.B. Giordano (eds.), Tomate para processamento industrial, Brasília, Embrapa Comunicação para Transferência de Tecnologia.

Obradovic, A., Mavridis, A., Rudolph, K., Janse, J.D., Arsenijevic, M., Jones, J.B., Minsavage, G.V. and Wang, J.-F. 2004. Characterization and PCR-based typing of Xanthomonas campestris pv. vesicatoria from peppers and tomatoes in Serbia. Europ. J. Plant Pathol. 110:285-292.

O’Garro, L.W. 1998. Bacterial spot of tomato and pepper on four East Caribbean islands: races, their abundance, distribution, aggressiveness, and prospects for control. Plant Dis. 82:864-870.

Quezado-Duval, A.M. and Camargo, L.E.A. 2004. Raças de Xanthomonas spp. associadas à mancha-bacteriana em tomate para processamento industrial no Brasil. Hort. Bras. 22:80-86.

Quezado-Duval, A.M., Gazzoto Filho, A., Leite Júnior, R.P. and Camargo, L.E.A. 2003. Sensibilidade a cobre, estreptomicina e oxitetraciclina em Xanthomonas spp. associadas à mancha-bacteriana em tomate para processamento industrial. Hort. Bras. 21:670-675.

Quezado-Duval, A.M., Leite Jr., R.P., Truffi, D. and Camargo, L.E.A. 2004. Outbreaks of bacterial spot caused by Xanthomonas gardneri on processing tomato in central-west Brazil. Plant Dis. 88:157-161.

Warner, J. 2003. Crop Protection. Ontario Horticultural Crops Research and Services Comittee 2002 Annual Report - Tomato. www.gov.on.ca

Wilson, K. 1999. Preparation of genomic bacteria. p.2-14. In: F.M. Ausubel, R. Brent, R.E. Kingston, D.D. Moore, J.G. Seidman, J.A. Smith and K. Struhl (eds.), Short protocols in molecular biology, New York, NY: John Wiley.

\section{Tables}

Table 1. Phenotypic differential characteristics ${ }^{1}$ among PFGE groups of Xanthomonas spp. from processing tomato in Brazil.

\begin{tabular}{ccccccccc}
\hline PFGE & Copper & Strept $^{2}$ & AM & PEC & Protein & Tomato & Pepper & T race $^{3}$ \\
\hline 1 & $5 \%$ & $58 \%$ & - & - & $\alpha$ & + & + & T1 \\
2 & $3 \%$ & $0 \%$ & + & + & $\beta$ & + & - & T3 \\
3 & $74 \%$ & $2 \%$ & + & + & $\beta$ & + & - & T2 \\
4 & $48 \%$ & $98 \%$ & - & - & $\beta$ & + & v & T2
\end{tabular}

${ }^{1}$ Pulsed field group (PFGE); percentage of in vitro resistant strains to copper sulfate (50 $\left.\mu \mathrm{g} / \mathrm{ml}\right)$ and to streptomycin sulfate (25 $\mu \mathrm{g} / \mathrm{ml})$; amylolytic (AM) and pectolyctic (PEC) activities; presence of typical protein band in SDS-PAGE; pathogenicity on tomato and pepper, and race based on hypersensitive reaction on differential tomato genotypes and presence of avirulence genes.

(+): positive; (-): negative; (v): variable among strains. 
Table 2. Populational composition and frequency of xanthomonads associated with bacterial spot on processing tomato fields in Brazil from 1995 to 2003.

\begin{tabular}{ccccccc}
\hline Local/Year & Number & Number & \multicolumn{5}{c}{ Frequency of species/groups (\%) } \\
\cline { 6 - 8 } & of strains & of fields & XE - A & XV - B & XP - C & XG - D \\
\hline Northeast & & & & & & \\
1996 & 36 & 4 & 100 & 0 & 0 & 0 \\
1998 & 54 & 12 & 33.3 & 0 & 66.7 & 0 \\
\hline Central-West & & & & & & \\
1995 & 142 & 4 & 1.4 & 98.6 & 0 & 0 \\
1997 & 67 & 5 & 0 & 3.0 & 0 & 97.0 \\
1998 & 80 & 4 & 7.5 & 0 & 0 & 92.5 \\
2000 & 85 & 4 & 0 & 0 & 0 & 100 \\
2002 & 48 & 3 & 0 & 0 & 54.2 & 45.8 \\
2003 & 5 & 3 & 0 & 0 & 100 & 0 \\
\hline
\end{tabular}

${ }^{1}$ XE: Xanthomonas euvesicatoria; XV: X. vesicatoria; XP: X. perforans; XG: X. gardneri (Jones et al., 2004). A, B, C, and D: genotypic and phenotypic groups.

\section{Figures}

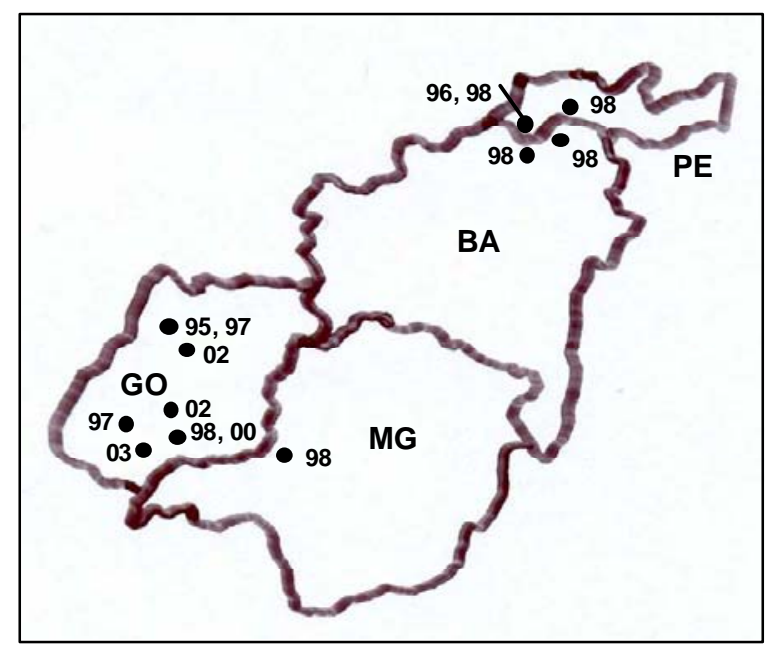

Fig. 1. Locality and year for bacterial spot samplings in the Northeast (states of Pernambuco - PE - and Bahia - BA) and Central-West of Brazil (states of Goiás GO - and Minas Gerais - MG). 


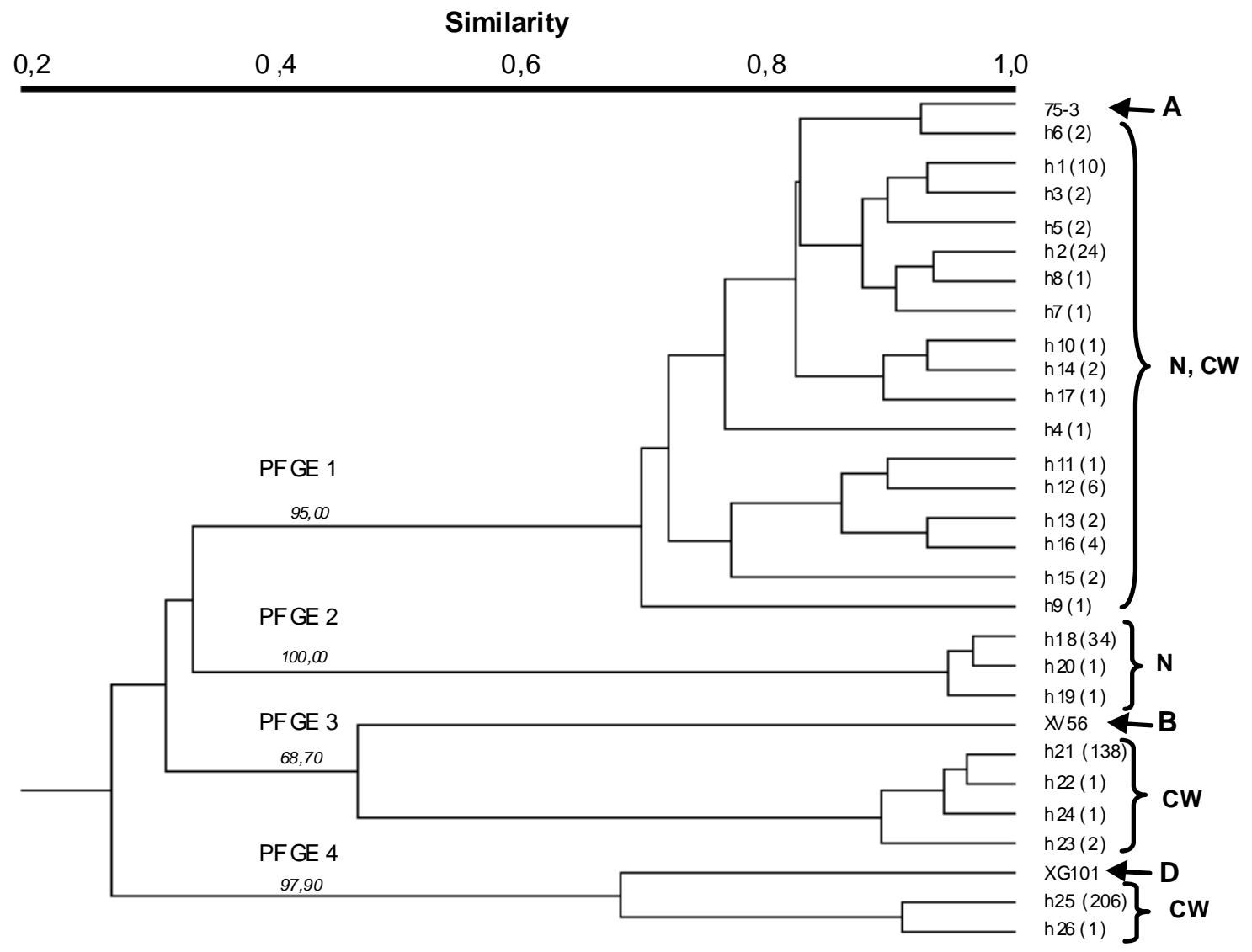

Fig. 2. Clustering of strains of Xanthomonas spp. isolated from Brazilian processing tomato fields inferred from similarity coefficients obtained from $X b a$ I restriction endonuclease data. Bootstrap values after 1,000 permutations are indicated in italic. Number of strains represented by each haplotype are in parenthesis. The arrows indicate the group representative strain. Arrows: reference strains for groups A, B and D. N: Northeast; CW: Central-West. 